\title{
ISLAMIC RELIGIOUS VALUES IN SAPTA TIRTA PABLENGAN FOLKLORE
}

\author{
Rahayu Nur Istiana*, Ani Rakhmawati, and Nugraheni Eko Wardani \\ Universitas Sebelas Maret \\ *Email: istianayaya@gmail.com
}

Received: September 13, 2021

Accepted: November 13, 2021

\section{Abstract}

"Sapta Tirta Pablengan" folklore which is originated from Karanganyar Regency, Central Java, is one of Javanese identities with a lot of local values and wisdom. This study aims to describe and explain Islamic religious values behind "Sapta Tirta Pablengan" folklore. It is a descriptive qualitative research with content analysis method. The data were collected through literature study, structured and in-depth interviews, and field observations. The data analysis employed independent techniques and flow analysis techniques. The results of the study show that the Islamic religious values of Sapta Tirta Pablengan folklore could be grouped into three dimensions along with their respective indicators. The first is faith dimension with indicators: (1) believing in Allah, (2) believing in His destiny, (3) surrendering to Him, (4) sincere, and (5) practicing worship. The second is experience dimension with indicators: (1) helpful, (2) honest, (3) forgiving, and (4) hard work. The third category is natural dimension with the indicator of managing and conserving nature. Therefore, "Sapta Tirta Pablengan" folklore can be recommended a learning material at schools because it contains Islamic religious character education.

Cerita rakyat "Sapta Tirta Pablengan" yang berasal dari Kabupaten Karanganyar, Jawa Tengah, merupakan salah satu jati diri masyarakat Jawa yang sarat akan nilai-nilai dan kearifan lokal. Penelitian ini bertujuan untuk 
mendeskripsikan dan menjelaskan nilai religius Islam yang terkandung dalam cerita rakyat "Sapta Tirta Pablengan." Jenis penelitian ini adalah deskriptif kualitatif dengan metode analisis isi. Metode pengumpulan data dengan studi pustaka, wawancara terstruktur dan mendalam, serta observasi lapangan. Teknik analisis data menggunakan teknik mandiri dan teknik analisis mengalir. Hasil kajian menunjukkan mengandung nilai religius Islam dikelompokkan menjadi tiga dimensi beserta indikator yang menyertai. Pertama, dimensi keyakinan dengan indikator: (1) percaya adanya Allah, (2) percaya pada takdir Allah, (3) pasrah pada Allah, (4) iklhas, dan (5) menjalankan ibadah. Kedua, dimensi pengalaman dengan indikator: (1) suka menolong, (2) jujur, (3) pemaaf, dan (4) kerja keras. Ketiga, dimensi alam dengan indikator mengelola dan melestarikan kekayaan alam. Dengan demikian, cerita rakyat "Sapta Tirta Pablengan" bisa direkomendasikan sebagai materi pembelajaran sastra di sekolah karena sarat dengan pendidikan karakter religius.

Keywords: folklore; "Sapta Tirta Pablengan"; Islamic Religious Values; Religious Dimensions

\section{Introduction}

Indonesia is an archipelagic country with diverse ethnic groups and cultures. The existing cultural diversity symbolizes the identity of a nation because culture embraces values and local wisdom. One of the cultures of the Indonesian is oral literature (Sujiono, 2019). Oral literature is closely related to the history of the nation under the socio-cultural, moral, religious, and even political aspects. It as a wealth belonging to the people with uniqueness and values that can be passed down from generation to generation. Folklore is a collective cultural element often transmitted to the next generation conveyed orally or through gesture (Sibarani, 2013). Similarly, Iminisa et al. (2016) wrote folklore as a cultural tradition among a group of communities that transmits from generation to generation.

One of the oral literatures is folklore. It is a wealth of cultural repertoire that circulates by mouth without any authorship. It is completely different from printed work with the identified author (Khan, 2018). Taylor (in Singh, 2019) defined folklore as a material handed down by tradition either by word of mouth or by custom. According to Endraswara (2013), it is an oral folklore genre delivered from generation to generation. It symbolically reflects personal expectations (Das, 2014). 
One of the oral literatures that has been developing among Karanganyar community is the folklore or legend of Sapta Tirta Pablengan. According to the cultural figures in Karanganyar, there are two versions of characters in Sapta Tirta Pablengan folklore growing among the community. The earlier version is developed with the characters of Ajisaka and Naga Linglung while the later one is called Raden Mas Said (Mangkunegara I). The difference in character versions happens naturally because folklore is an oral story spread by word of mouth, similar to the two versions of the Legend of Rawa Pening associated with the characters of Baru Klinting and Jaka Bandung (Sumiyardana, 2018).

Sapta Tirta Pablengan folklore was documented in 2010 by Maryanto \& Raharjanti titled Cerita Rakyat dari Karanganyar, Jawa Tengah (A Folklore from Karangan, Central Java) published by PT Grasindo, Jakarta. This book is introduced by Mrs. Rina Iriani Sri Ratnaningsih, the former Regent at that time. This book contains a collection of nine folklores from Karanganyar. One of the subtitles is Asal Mula Sapta Tirta Pablengan telling the protagonist Ajisaka and Naga Linglung while the folklore with the protagonist Raden Mas Said has never been written. After the interviews, literature reviews, document analysis, and direct observation, the author transliterated Sapta Tirta Pablengan folklore with the version of Raden Mas Said as the protagonist. The documentation of Sapta Tirta Pablengan folklore is expected to be helpful for the community to acknowledge the folklore and transmit it to the younger generation that it is well preserved as a cultural heritage with noble values.

Shortly, it is told that the seven springs in Sapta Tirta Pablengan were formed after Naga Linglung wanted to come to the surface. The trace of Naga Linglung body then created seven holes, which were the sources of the seven springs. Naga Linglung was the son of Ajisaka. He was very devoted to his parents. It was evidenced by Ajisaka who carried out his father's orders to fight the giant white crocodile in the South Sea, the incarnation of Dewata Cengkar. Devotion to parents is one of the implementations of religious values. Ajisaka is a religious figure who has righteous thoughts, holds fast to religion and truth, and does not sway in life (Sari et al., 2018).

Another version growing among the community is the Sapta Tirta Pablengan folklore associated with the struggle of Raden Mas Said (Mangkunegara I). Raden Mas Said's long struggle for sixteen years cannot be separated from his religious experience. It is told that he meditated on Argotiloso hill and received instructions to dig seven holes under Argotiloso Hill which became the source of Sapta Tirta's springs. These seven sources were used to bathe him and his 
troops before fighting the Dutch colonialists. During the struggle against the enemies, he could control himself by being grateful and contemplating the presence of God, and trying to find solutions (Hendro, 2017). Raden Mas Said is also a figure who lives independently and lives a life rooted like a man as a creature of God.

Sapta Tirta Pablengan is located in Pablengan, Matesih, Karanganyar, approximately $31 \mathrm{~km}$ from Surakarta. Surakarta is the civilization center of Mangkunegaran Palace. As in historical records, in 1755 Mataram in Surakarta was divided into two, the Kasunanan Palace and the Mangkunegaran Palace. Raden Mas Said fought against the Dutch colonialists to obtain his right as the testator of Surakarta Palace. The heroism and nationalism values were dominant in folklore with Raden Mas Said or well known as Sambernyowo Prince as the protagonist (Puspitasari, 2018; Haq, 2012).

Raden Mas Said fought against VOC to maintain the integrity of The Islamic Mataram. Raden Mas Said, as the protagonist in Sapta Tirta Pablengan folklore, embody a lot of values of religious education, morals, history, heroism, and nationalism (Suryadi, 2017; Puspitasari, 2018). It is known that the Islamic Mataram Sultanate founded in 17th century held an important role in the history of the Islamic kingdom in the archipelago. Until 1755 with the intervention of the VOC, the Islamic Mataram area in Surakarta was divided into two, which was the Surakarta Kasunanan Palace and the Mangkunegaran Palace. According to The Giyanti agreement, Raden Mas Said was recognized as a king in Mangkunegaran. As a king, he did a lot of Islamic da'wah through local cultural approaches, such as traditional dances, Wayang Orang, and copied the Qur'an in pegon Arabic (Yayasan Mangadeg Surakarta, 1988). This strategy was implemented as Hindu had entered and widely spread in the archipelago in the 13th century.

Religious values can be seen from human activities to God, to other humans, and to nature (Mangunwijaya in Maulidianto, 2021). Muhaimin (1991) noted that Islamic values based on their sources can be classified into two, God values and human values. God values are sourced from the Qur'an and hadith while human values develop according to the agreement derived from customs and natural facts. Religious values can be included in three dimensions along with the indicators, such as Allah, tawakal, taqwa, patience, and helpfulness (Glock \& Stark, 1966; Zuriah, 2015; Rabbi \& Jauhari, 2006). Javanese cultural products are closely related to religious values, such as in 
Serat Wedhatama by K.G.P.A.A. Mangkunegara IV with five dimensions of religiosity (Putro et al., 2021).

Researches on Islamic religious values in Javanese cultures have widely been conducted, such as those in tembang macapat, manuscript, traditional ceremonies, Javanese idiom, and folklore (Saddhono, 2018; Wati, 2019; Kasnadi, 2018; Nursari, 2020; Saefudin, 2020). Tembang macapat teaches Islamic religious values to humans. The results of Islamic religious values in traditional ceremonies are written more detail as follows: faith, Islam, taqwa, tawakal, aqidah, worship, sincerity, gratitude, patience, honesty, and discipline. It is also strengthened by Islamic values in Javanese idioms, such as belief, prayer, surrender, and gratitude to Allah. The Islamic values are also found in Javanese folklore. The values found are the accompanying indicators of the religious dimension, but they have not been grouped into the religious dimension.

One of the local cultures that contains Islamic religious values is folklore. The values usually lie within the protagonists who believe in the existence of God and surrender to Him (Dewi 2012; Fatimah, 2017). Folklore has the characteristics of containing ideas, cultural traditions, and scientific values conveyed orally to the following generations. Folklore, myths, and traditions in Raden Mas Said's relic provide benefits in terms of spiritual, social, and cultural preservation or tradition, as well as economics (Aryanti, 2017). However, nowadays the younger generation tends not to know folklore especially the noble values within. The values within folklore, such as humanist and caring for the environment, must be transferred from the early age to the younger generation (Claudia et al., 2021). According to Rahiem (2020), folklore has the potential to be a promising platform for educating the younger generation and children about disaster prevention, preparedness, response, and recovery.

Folklore can be strengthening materials of character education for students. One of the informants who studied at an elementary school in 1950 told that his teacher often told him about folklore. It was told that birds could live again after drinking the Air Hidup (The Living Water) in Sapta Tirta Pablengan. Learning by a contextual approach using folklore from the surrounding area helps students know the local culture. Folklore can be used as a teaching material to introduce the cultural heritage to the younger generation. Thus, the local cultural heritage remains sustainable. However, nowadays teachers rarely use local folklore as the teaching material. They mostly depend on textbooks, so the students do not know local folklore. 
Therefore, the author analyzes the Islamic religious values in Sapta Tirta Pablengan folklore to promote them to the public, especially the younger generation. The use of folklore as the learning materials can provide understanding about the values of character education to the students (Hastuti et al., 2021). The Islamic religious values within folklore could possibly be explored, studied, and preserved. It, thus, is expected that Sapta Tirta Pablengan folklore will always sustainable in the community and be interpreted as a literacy heritage with Islamic religious values, noble values, and local wisdom.

\section{Method}

The current research employed qualitative descriptions by transliterating Sapta Tirta Pablengan folklore. The first data collection technique is direct observation, recording, interviewing, and writing. The data analysis referred to the synthesis from Glock \& Stark (1966) and Zuriah (2015) theory which grouped religious values into three dimensions with indicators.

The data were validated with data triangulation and method triangulation. The data triangulation was done by comparing information from one informant to the others. Method triangulation was made by comparing the data obtained through observation, interviews, and document analysis.

\section{Finding \& Discussion}

\section{The Overview of Sapta Tirta Pablengan Folklore}

There are two versions of Sapta Tirta Pablengan folklore according to the protagonists, Ajisaka and Naga Linglung and Raden Mas Said (Mangkunegara I) as the protaginist. Folklore with the Ajisaka and Naga Linglung as the protagonists came up earlier. The two mythologies were developed as folklore in Karanganyar Regency and still related to the historical events. It is intended to leave a history for the next generation. Folklore is a product of human thought which is an important genre from a folklore that symbolically reflects human expectations (Das, 2014).

Table 1. Kinds of Sapta Tirta Pablengan Folklore Based on Protagonist

\begin{tabular}{lll}
\hline No. & Name of Protagonist & Code \\
\hline 1 & Ajisaka and Naga Linglung & A \\
\hline 2 & Raden Mas Said & R \\
\hline
\end{tabular}




\section{Sapta Tirta Pablengan Folklore with Protagonist Ajisaka and Naga Linglung}

Ajisaka became a king in Medang Kamulan after defeating Dewata Cengkar who liked to eat human flesh. Dewata Cengkar was successfully thrown into the middle of the fierce South Sea. However, Dewata Cengkar did not perish, he instead transformed into a fierce white giant crocodile. At the time when the South Sea surged with waves as high as a mountain, it was a sign that the white giant crocodile rampaged and asked for victims of the fishermen at Medang Kamulan.

Ajisaka meditated and wandered to get clues to perish Dewata Cengkar. When he arrived at a quiet hill, Ajisaka prayed for God's guidance. For days, Ajisaka united all heart and mind to ask God's help. In his wanderings, Ajisaka dripped the sweat which became descendant, namely Naga Linglung.

Naga Linglung was looking for Ajisaka to be recognized as a child. Ajisaka would recognize Naga Linglung as a child as long as he could kill Dewata Cengkar. Naga Linglung succeeded to kill Dewata Cengkar but badly injured that he was confused and could not find a way to go home. Naga Linglung infiltrated the ground and appeared to the surface. However, Naga Linglung actually appeared in the Pablengan area, not in Medang Kamulan. The place from which Naga Linglung came up became Sapta Tirta Pablengan.

\section{Sapta Tirta Pablengan Folklore with Protagonist Raden Mas Said}

The struggle of Raden Mas Said against his enemies to defend Mataram lasted for 16 years. In his long struggle, Raden Mas Said also experienced fatigue and exhaustion (body and soul). Raden mas Said calmed his body and soul by meditating at Argotiloso Hill. Raden Mas Said also made Argotiloso hill, a place to exchange ideas with his younger brothers, Ambiya and Sabar, in formulating a war strategy against the Dutch.

Raden Mas Said received revelation to take a magic heirloom, Tunggul Naga spear, that could make him disappear, with which he successfully defeated the Dutch. Finally, Raden Mas Said was appointed as a king with the title Gusti Mangkunegara I. After becoming a king, he felt less prestigious and then return to meditate. Raden Mas Said received revelation again to take Tambur Sedbyo heirloom and Wesi Kuning heirloom at Mengadeg, Matesih District.

Argotiloso Hill is a place for Raden Mas Said to meditate and to gain revelation. In this place, he can feel calm and peaceful so that he can cultivate his mind. He received revelation again to grout seven holes under Argotiloso 
Hill which was later named Sapta Tirta, means seven waters. The names of seven water sources are Air Bleng, Air Hangat, Air Kasekten, Air Hidup, Air Mati, Air Soda, and Air Urus-urus.

\section{Islamic Religious Values in Sapta Tirta Pablengan Folklore}

This study used a synthesis theory of Islamic religious values from Glock \& Stark (1966) and Zuriah (2015). Islamic religious values grouped into three dimensions and their indicators. The first is believing in Allah, the human relationship with Allah, with indicators of believing in Allah's destiny, surrendering to Allah, being sincere, and performing worship. The second is the experience dimension with indicators of helpfulness, forgiveness, honesty, and hard work. The third is natural dimension (human relations with nature) with the indicator of managing and preserving nature. These values need to be instilled in human beings, especially the younger generation to achieve better and peaceful life. The analysis was carried out by reading Sapta Tirta Pablengan folklore, analyzing Islamic religious values, and classifying Islamic religious values into three dimensions and their accompanying indicators.

\section{Belief in Allah}

Believing in God as Islamic religious value is reflected in Ajisaka who always prays to God to get guidance upon fighting against the Giant White Crocodile in the southern sea, the incarnation of Dewata Cengkar. Ajisaka also asked to God for the clues. In the end, Ajisaka arrived at a village which he believed as a clue from God. Believing in God dimension is also found in Raden Wijaya folklore from Trowulan, Mojokerto where Raden Wijaya always asked for guidance before establishing the Majapahit Kingdom (Sujiono, 2019). It can be seen in two version of Sapta Tirta Pablengan Folklore, as follows:

Akhirnya permohonannya yang sungguh-sungguh dikabulkan oleh Sang Pencipta. Samar-samar dia mendengar sebuah suara gaib. (A/28)

[Finally, his earnest request was granted by God. Disguised, he heard a mysterious voice.] (A/28)

Setelah beberapa hari berjalan dan tak lupa di sepanjang jalan terus memohon petunjuk dari Sang Pencipta, sampailah raja di sebuah desa. "Mungkin ini desa yang dimaksud dalam petunjuk gaib itu." Kata Raja Medang Kamulan itu di dalam hatinya. (A/29) [After a few days walking and praying to God along the way, the king arrived in a village. "Perhaps this is the village as means in that magic clue." The King of Medang Kamulan said in his heart.] (A/29) 
Dengan kata-kata yang melengking bergemuruh di atas punggung kuda masing-masing mereka berseru "Allahu Akbar" (hu, hi) biarlah mati dalam perang sabil, mereka maju bagaikan Harimau lapar menerkam musuh-musuhnya. (R/2)

[With shrill voices on the backs of their horses they exclaim "Allahu Akbar" (hu, hi) let die in a war of sabil, they advanced like hungry tigers to pounce on their prey.] (R/2)

Raden Mas Said and his soldiers fought against VOC as faith to God by saying Allahu Akbar (Allah is Great). He was a knight who was hard to beat, always asked for help, and only surrendered his life to Allah (Haq, 2012). The quote above implies Islamic religious values for faith dimension, which is believing in the existence of God. In Islam, the value of faith is not only taught to Allah but also to the Prophet Muhammad and the Qur'an as written in Surah An-Nisa: 136. There is faith to God further fueled the spirit to fight VOC even though their lives as guarantee. Moreover, it is as like Sabil war, the war by the people of Aceh in expelling the Dutch.

\section{Belief in Allah destiny}

Naga Linglung came from the droplets of Ajisaka's sweat. Naga Linglung was basically an unwanted child. Ajisaka was described as a respected and authoritative character but had a child with a shape a dragon. This incident means that even good people will get rewarded according what they have done. If they do indecent acts, they will get unpleasant replies (Sumiyardiana, 2018). It can be inferred from the quote below:

Sang Raja sangat gembira karena di dalam semadinya sudah mendapat petunjuk tentang kedatangan naga yang akan menjadi penolongnya itu. (A/33)

[The King was very happy because in his meditation received clue about arrival of the dragon who would be his helper.] (A/33)

Ajisaka believed that the power of Allah would come to help him and people of Medang Kamulan to fight the giant white crocodile. Naga Linglung was destined to defeat the giant white crocodile when he arrived at Medang Kamulan. One of religious education values in society is manifested in the belief in supernatural powers that will bless everything to done (Maryone, 2021). Belief in Allah destiny can also be seen from this quote:

Raden Mas Said mendapatkan wahyu sewaktu bertapa, yaitu mendengar bisikan gaib agar ia mengambil sebuah pusaka sakti yakni tombak Tunggul Naga yang dapat membutnya menghilang. Dengan menggunakan tombak tersebut, Raden Mas Said kembali mengadakan perlawanan terhadap Belanda. Kali ini Raden Mas Said dengan mudah mengalahkan tentara Belanda. Setelah mengalami kemenangan dan berhasil melumpukan Belanda, Raden Mas Said kemudian diangkat menjadi raja dengan gelar Gusti Mangkunegara I. (R/2) 
[When Raden Mas Said had a meditation, he got a supernatural whisper as the divine revelation. The revelation commanded Raden Mas Said to take the Tunggul Naga heirloom spear as tool to fight the Dutch. This spear could make him disappear. He used the Tunggul Naga spear to fight against Dutch colonialists. Raden Mas Said then succeed in crippling the Dutch. Then, he was appointed as the king with the title Gusti Mangkunegaran I.] (R/2)

Folklore is full of miracles resembling myths, past time and sometimes contains religious material, but it does not have beliefs (Van Baal in Baiduri, 2020). Raden Mas Said believed in God's destiny that his struggle against the Dutch would result in victory even though the weapons used were just a spear. He still maintained their own weapons such as spears, kris, swords, and bows (Ricfklefs, 2021).

One of Islamic values is sourced from Al Qur'an and hadith. Belief of Allah's destiny as written in Al Qur'an Surah Ar-Ra'd:11 that Allah will not change people's condition until they change it their own. And if Allah wills evil for a people, no one can refuse it, and no protector except Allah. Ajisaka and Raden Mas Said practiced Islam by trying and praying for situation to be better.

\section{Surrender to Allah}

Surrender to Allah means tawakal, to surrender everything to Allah. Tawakal will make a person's heart and mind peaceful. There is no suspicion since recognizing that Allah is The All-Knowing and The All-Wise (Ad-Dumaiji, 2006). The value of surender to Allah can be found in folklore with protagonist Ajisaka and Raden Mas Said as follows:

Berhari-hari Raja Medang Kamulan itu menyatukan segenap hari dan pikirannya untuk memohon pertolongan Sang Pencipta. (A/28)

[For days the King of Medang Kamulan united all his days and thoughts to ask for help to Allah.] (A/28)

Ajisaka tried for days until he came to the point of leaving everything to Allah and asking for clues to solving the problem, fighting the giant white crocodile. Surrender to Allah not only means resting the body but also the mind. When the body rests, it is balanced with the spiritual. At the time, human said restfully. Tawakal means letting go of body and heart with divinity, surrendering to qada and qadar of Allah, feeling sufficient, grateful, and patient (Sukardi \& Sulistiyono, 2019).

The value of surrender to Allah or tawakal in folklore is used as a guide to the way of life (Hijiriah, 2017). Raden Mas Said left the palace and fought 
the Dutch to realize the peaceful Mataram based on surrender to Allah. Raden Mas Said surrendered all life and death to Allah while fighting with his soldiers. Surrendering everything to Allah does not mean despair but a form of belief and hope that behind difficulties there must come ease and happiness (Haq, 2012). It is as reflected by the following quote:

Kelima adalah sumber air mati yang memiliki makna umur dan mati Raden Mas Said senantiasa dipasrahkan pada Tuhan Yang Maha Esa. (R/4)

[The fifth is Air Mati which has the meaning Raden Mas Said's age and death always surrender to Allah.] (R/4)

Raden Mas Said took a bath with Air Mati (Dead Water) at Sapta Tirta Pablengan and always prayed to Allah. The philosophical value of Air Mati is that life and death are always absolute in life. Humans must experience life and death. There must be death and eternal life after death. These two are reminders in life.

Javanese's spirituality introduces mati sajroning urip (the practice of dying), or "mati dalam hidup" (dying in life). It means that they will achieve happiness and life glory when the body is dead or returns to Allah. Javanese culture teaches "Mulih mula nira, sangkan paraning dumadi" (humans return to their origins and human life purpose) (Rahyono, 2015). They must be able to "meper" [control] or kill all bad traits, lust, and greed inside their body.

\section{Sincerity or Ikhlas}

Sincere refers to the human's purity doing something only for Allah. Ajisaka fought Dewata Cengkar without expecting anything but wanted a good job to save people at Medang Kamulan. Sincere means doing everything only for Allah, without expecting anything and without coercion (Nursari et al., 2020). It is written in the Quran, Surah Al-Insan: 8-9 which translates "(8) And they give the food they like to the poor, orphans, and captives, (9) (saying), "Indeed, we give you food just pleasure blessing to Allah, we do not expect thanks from you. (9)". Sincere values can be seen as follows:

Dengan kesaktian Ajisaka, Raja Dewata Cengkar berhasil diceburkan ke tengah Laut

Selatan yang ganas. (A/27)

[By Ajisaka's magic, King Dewata Cengkar was successfully thrown into the middle of the fierce South Sea. (A/27)]

Raden Mas Said experienced hard life problems since childhood. His father was slandered and exiled to Sri Lanka, and then his mother passed away. At the time, he was still 2 years old. Everything passed patiently and sincerely with his two brothers R.M. Ambia and R.M. Patience (Yayasan Mangadeg 
Surakarta, 1988: 15). They were almost excluded from palace life and mostly played with the courtiers' children as quoted below:

Ketidakadilan dimulai ketika Pangeran Arya Mangkunagoro dibuang oleh Belanda ke Srilangka (Ceylon) karena difitnah oleh patih Danurejo. Dalam fitnah itu dikatakan bahwa Pangean Arya Mangkunagoro berziah dengan selir Pakubuwono II (Penerus Pakubuwana I yang wafat) yang bernama Mas Ayu Larasati. Pada awalnya P. A. Mangkunagoro dijatuhi hukuman mati, namun diubah menjadi hukuman buang. Pada waktu itu Raden Mas Said masih berumur 2 tahun. Begitu juga dengan ibu Raden Mas Said yang meninggal ketika melahirkan. (R/1)

[Injustice began when Prince Arya Mangkunagoro was exiled the Dutch to Sri Lanka (Ceylon) because slandered by the Danurejo governor. Said that Prince Arya Mangkunagoro was fornicate with married Pakubuwono II concubine (the successor of Pakubuwana I) named Mas Ayu Larasati. At first, P. A. Mangkunagoro was sentenced to death, but it was changed to banishment. At that time Raden Mas Said was 2 years old. Likewise, with Raden Mas Said's mother passed away at childbirth. (R/1)]

Urutan selanjutnya, empat adalah Raden Mas Said mandi di sumber air hidup yang bertujuan agar apa yang dicita-citakan selama hidupnya dapat tercapai. (R/3)

[In the next sequence, Raden Mas Said took a bath with "Air Hidup" with the aim to achieve what he aspires during his life. $(\mathrm{R} / 3)]$

Raden Mas Said with his soldiers did long struggle for 16 years fighting the Dutch, and he must have gone through many obstacles. In the end, all obstacles could be overcome with sincerity. One of the efforts by Raden Mas Said was taking a bath with "Air Hidup" at Sapta Tirta Pablengan with the aim achieved what he aspired during his life. Everything done with sincerity will get a good reward even more (Maulidianto, 2021). "Air Hidup" has means that humans are ready to live life when they can purify their body and mind. "Air Hidup" is always turbulent that illustrates that human life must have ups and downs, happiness, difficulty, all that life's problems from Allah that must be passed with sincerity.

\section{Worship}

Ajisaka's character is described as a person who diligently performs worship. As well as Raden Mas Said who treated physical and mental fatigue while fighting the Dutch by worshiping and meditating on Argotiloso Hill. The dimension of worship or ritual is related to someone carrying out their religious obligations (Glock \& Stark in Ancok, 2011). The goal is the same, asking Allah for help while at the same time calming the soul and body. Recovery of mind and energy is highly prominent psychologically as a weapon to fight with the Dutch. It is as reflected in the following quote: 
Ketika perjalanannya sampai di sebuah bukit yang sunyi, Ajisaka pun kemudian bertapa untuk memohon petunjuk sang pencipta. Berhari-hari Raja Medang Kamulan itu menyatukan segenap hati dan pikirannya untuk memohon pertolongan Sang Pencipta. (A/28)

[When his journey reached a deserted hill, Ajisaka meditated to ask for a clue to God. For days, the King of Medang Kamulan united all hearts and thoughts ask help from God. (A/28)]

Dalam perjuangan panjangnya Raden Mas Said juga pernah mengalami kekelahan, kelelahan (jiwa dan raga). Raden mas Said menenangkan jiwa dan raganya dengan bertapa di Bukit Argotiloso. (R / 2)

[In his long struggle, Raden Mas Said also experienced fatigue, exhaustion (body and soul). Raden mas Said calmed his body and soul by meditating on Argotiloso Hill. (R/2)]

Meditation or in Javanese terms, "semedi" is a worship carried out by Ajisaka and Raden Mas Said. Meditation is a form of traditional values in folklore (Sujiono, 2019). Haq (2012) uses the term "tahanuts" to describe Raden Mas Said that meditates and gets two heirlooms as sign to continue fight the Dutch. Thus, meditation or "semedi" contains not only religious value but also a traditional custom or acculturation from religious and cultural values. Islam presents assimilated in the middle of local culture and builds a harmonization between beliefs based on religion and belief of the mystical (Artawijaya in Rahmaniar, 2020).

\section{Being Helpful}

Helpful is one of the Islamic values written in the Quran Surah Al Maidah: 2, which means "and help you in goodness and taqwa, and do not help in sins and transgressions. And taqwa to Allah, really Allah torment is very hard". Ajisaka helps the people of Medang Kamulan without long thinking though risking his life, like the village woman who gives drinking water because he sees Ajisaka very thirsty. Humans as social beings should help each other regardless of background, position, or social status because they are the same according to Allah (Juanda, 2019). Village female figures help without thinking about the social status of the people being helped, be it from the common people or the king. At that time, Ajisaka disguised himself as a commoner and the village woman kept helping Ajisaka. Both of these characters are described as helping for a sense of sincerity and selflessness as seen in the quote below:

Ajisaka menjadi raja di Medang Kamulan setelah berhasil menyingkirkan Raja Dewata

Cengkar yang konon suka makan daging manusia. Dengan kesaktian Ajisaka, Raja 
Dewata Cengkar berhasil diceburkan ke tengah Laut Selatan yang ganas. Namun, Raja Dewata Cengkar tidak binasa, dia justru menjelma jadi seekor buaya raksasa putih yang ganas. (A/27)

[Ajisaka became king in Medang Kamulan after defeating the King Dewata Cengkar that liked to eat human flesh. With Ajisaka's magic, King Dewata Cengkar was successfully thrown into the middle of the fierce South Sea. However, King Dewata Cengkar did not die, he instead transformed into a fierce white giant crocodile. (A/27)]

Perempuan desa yang baik hati itu segera mengambil segayung air ketika dilihatnya Ajisaka yang menyamar sebagai seorang pengembara itu tampak sangat kehausan. Keringat Ajisaka yang begitu banyak menetes dengan deras di atas tanah saat menunggu perempuan desa itu mengambil air. (A/29)

[The kind village woman immediately took a jug water when she saw Ajisaka disguised as a traveler looking very thirsty. Ajisaka's sweat dripped profusely on the ground while waiting the village woman take water.] (A/29)

Raden Mas Said moved to fight the Dutch for helping peoples who lived miserably because arbitrariness of the Dutch. Religious values can be seen in human relationships with other people by helping each other and helping those who have difficulties (Maulidianto, 2021). It can be inferred from the following quote:

Raja baru Pakubuwana II pun tidak berani bersikap tegas terhadap Belanda bahkan tidak memiliki pendirian yang tetap. Hal itu membuat para kerabat keraton melakukan perlawanan, salah satunya pihak Raden Mas Said (R/1)

[The new king Pakubuwana II don't dare assert to Dutch and do not have a strong stance. This made the relatives of the palace get fight, include Raden Mas Said (R/1)].

The Dutch were unjust in interfering with the internal of the kingdom, creating hostility among the relatives of the palace. Therefore, the folklore embedded the values of crimes, such as injustice, cunning, torture, and fraud (Juanda, 2019). This statement reinforced the theory that the characters in folklore are traditional, some of which are good and some are bad, and sometimes contains animal characters (Barone, 2011).

\section{Honesty}

The village woman answered honestly that Raden Ajisaka had left the village. In the Quran Surah Al-An'am: 152, Allah obliges to speak the truth, "Wa izaa qultum fa'diluu walau kaana zaa qurbaa, wa bi'ahdillaahi aufuu, zaalikum washshookum bihii la'allakum tazakkaruun" thah means "When you speak, speak the truth, even your relatives and fulfill Allah's promises. Thus, Allah commands you so you remember." The value of honesty inside folklore 
is one of the characteristics inherent in humans and is the main key to doing something (Adriyanti, 2019). It is reflected by the following excerpt:

"Raja Medang Kamulan? Berarti Gusti Ajisaka?"

"Benar, Biyung. Ayahku sang Ajisaka," lanjut anak naga itu lagi.

Mendengar semua keterangan anak naga ajaib itu, perempuan desa itu menjadi semakin ternganga. Dia sama sekali tidak menyangka seorang raja akan mengunjungi gubuknya. Sayang, raja hanya sebentar singgah di gubuknya.

"Sayang Baginda Ajisaka sudah pergi," ujar perempuan desa itu tampak kecewa. (A/30)

["The King Medang Kamulan? It means Ajisaka?"

"Right, Mother. My father is Ajisaka," said Naga Linglung

Hear all descriptions from Naga Linglung, the village woman getting restless. He did not expect a king to visit his hut. Unfortunately, the king only briefly stopped at his hut.

"Unfortunately, Your Majesty Ajisaka has left," said the village woman, looking disappointed. (A/30)]

Naga Linglung and the village woman were honest because they delivered the true information. Honest values are emphasized in folklore because all good deeds will bring goodness in the future (Fatimah, 2017). It is strengthened in H.R. Muslim no. 2607 "You should always be honest, honesty will obviously lead to goodness and goodness will lead to heaven...”. The honesty of the village women and Naga Linglung led to happiness because Naga Linglung could meet his father. In the end, Naga Linglung could defeat the giant white crocodile to bring tavern to the people of Medang Kamulan.

\section{Forgiving}

Ajisaka accidentally left his lineage, Naga Linglung, in a village. Naga Linglung forgave his father's inadvertence. In folklore, forgiving one's mistakes represented modesty (Afriyanti, 2018; Marsella, 2021). This story implied that Naga Linglung was forgiving, and he did not hold a grudge. He was even devoted to his father as shown below:

Naga itu sangat berterimakasih atas kesediaan Ajisaka mengakui dirinya sebagai putranya dan dia pun berjanji akan membunuh musuh kerajaan sebagai tanda baktinya. (A/34)

[Naga Linglung very grateful to Ajisaka's willingness that admit himself as his son and he also promised to kill the kingdom's enemies as sign of devotion.] $(\mathrm{A} / 34)$

The prophet of Muhammad taught peoples to forgive one another and create peace (H.R. Ibu Hibban). Even, the Qur'an Surah Ash-Shura: 40 and Al-Hujurat: 10 suggested that people who forgive and reconcile with each 
other will get reward from Allah. Therefore, improve the relationship between humans and those the pious [bertaqwa].

\section{Confidence}

Naga Linglung was remarkably confident because he was brave to fight Dewata Cengkar in the sea. It is stated in the quote below:

"Buaya putih! Bersembunyi di mana kau? Ayo hadapi aku, putra Ajisaka!" seru sang naga sambil mengibas-baskan ekornya untuk membuat gelombang. (A/ 34)

["White crocodile! Where are you hiding? Come to me, son of Ajisaka!" cried Naga Linglung while wagging the tail to make waves.] (A/34)

For his loyalty to Ajisaka and the people of Medang Kamulan, Naga Linglung threw himself into the sea without any soldiers. In Qur'an Surah Ali Imran: 139, Allah commanded people to have confidence and not be weak. In the Quran, Allah will level up the faith of those who have remarkable confidence. He commended people to strengthen their stance, not to feel afraid, sad, yet to be happy [Surah Fusshilat: 30].

\section{Preserving Nature}

Raden Mas Said found a clue of spring and then called it Sapta Tirta Pablengan, which meant seven springs with different efficacy. Sapta Tirta was a natural wealth given by Allah, so it must be used and managed well. In the Qur'an Surah Ar Rum: 41-42, humans as caliphs on earth are responsible for managing and preserving the cosmos for humans' benefit. Keeping the communication between humans and nature is a form of religious attitude for Javanese. They usually called it "jagad gedhe/alam" [the great universe/ nature] and "jagad cilik/manusia" [the little universe/humans] (Rahyono, 2015). One of the values related to the natural conservation behind the story is the fact that Raden Mas Said and his soldiers used "Air Bleng" as a symbol to unite their determination, mind, heart, and strong will to repel the Dutch colonialists as shown below:

Saat bertapa di Bukit Argotiloso, Raden Mas Said mendapat wisik untuk mandi dengan air Sapta Tirta. Makna sumber air Sapta Tirta Sebagai berikut:Air Bleng adalah air pertama yang dipakai oleh Raden Mas Said. Air Bleng bermakna ngeblengke (menyatukan) tekad, pikiran, hati dan keinginan untuk mengusir Belanda dari wilayah Mataram. Begitupun dengan para prajurit Raden Mas Said juga digembleng dan dimandikan dengan air Bleng untuk menempa diri. $(R / 3)$

[While meditating at Argotiloso Hill, Raden Mas Said received a clue to take a bath with Sapta Tirta. The meaning of Sapta Tirta is as follows: "Air Bleng" [Bleng water] was the first water used Raden Mas Said. "Air Bleng" means 
"ngeblengke" (unite) the determination, mind, heart, and desire to expel the Dutch from Mataram. Likewise, the soldiers of Raden Mas Said also trained and bathed with "Air Bleng" to forge themselves.] (R/3)

Tidak mengherankan jika kemudian sumber mata air ajaib tempat mumculnya Naga Linglung itu kemudian dijadikan tempat keramat oleh raja-raja Mangkunegaran dan kemudian diberi nama sumber mata air Sapta Tirta Pablengan. (A/36)

IIt is not surprising that later the magical spring where the Naga Linglung appeared was made a sacred place by the Mangkunegaran kings and called Sapta Tirta Pablengan spring.] (A/36)

Natural wealth from springs with seven different flavors was believed to come from the place where Naga Linglung appeared, and it was believed to be a magical source to preserve. Now, Sapta Tirta Pablengan becomes a natural tourism product which can be used as a lesson for future generations to understand the Javanese teachings of "memayu hayuning Bawana" [love nature and its contents]. The seven springs are believed to be originated from the Southern Ocean. These seven springs have different character, namely "air hangat, kesaktian, hidup, mati, soda, and urus-urus." The place where these seven springs appeared was deemed to be a sacred place by the Mangkunegaran kings and named after Sapta Tirta Pablengan. Today, Sapta Tirta Pablengan becomes a tourism object that can be visited by public. Preserving water with local wisdom can be done by making it a religious tourism object (Siswadi, 2011).

\section{Conclusion}

Sapta Tirta Pablengan folklore has two versions according to the protagonist characters, Ajisaka and Naga Linglung, and Raden Mas Said. The Islamic religious values within can be divided into three dimensions with some indicators: (1) the dimension of belief (human relationship with God) with the indicators of belief in Allah, belief in Allah's destiny, surrendering to Allah, sincerity, and worship; (2) the dimension of experience (human relations with themselves and others) with the indicators of being helpful, forgiving, honest, and hard-working; (3) the natural dimension (human relations with the natural environment) with the indicators of managing and conserving the nature. Islamic religious values can also be found in folklore in addition to Macapat and Serat. The Islamic religious values are also grouped into three dimensions with their respective indicators.

Islamic religious values are highly important to instill to the younger generation amid the moral decadence. The practical implications of Sapta Tirta Pablengan with a lot of Islamic religious values can be recommended as 
a learning material for literature at schools. Thus, further research is expected to examine the relevance of Sapta Tirta Pablengan folklore as a learning material for the subject of literature at schools.

\section{References}

Adriyanti, N. D., Suwandi, S., \& Subiyantoro, S. (2019). Nilai Kearifan Lokal dalam Cerita Rakyat Batu Gajah di Kabupaten Kudus. Prosiding Seminar Nasional Inovasi Pembelajaran Bahasa Indonesia di Era Revolusi Industri 4.0. Surakarta: Universitas Sebelas Maret, September 2019, 82-85.

Ad-Dumaiji, A. U. (2006). At-Tawakkal Alallah Ta'al. Jakarta: Darul Falah.

Afriyanti, M., Agustina, E. \& Canrhas, A. (2018). Nilai-nilai Pendidikan Karakter Cerita Rakyat Nasal sebagai Bahan Ajar Bahasa Indonesia SMP Kelas VII. Jurnal Ilmiah Korpus, 2(1), 56 -53.

Aryanti, R. (2017). Mitos Petilasan Pangeran Sambernyawa (Raden Mas Said) Wonten ing Astana Mangadeg Desa Girilayu Kecamatan Matesih Kabupaten Karanganyar Provinsi Jawa Tengah. Jurnal Penelitian Pendidikan Bahasa Jawa, 6 (4), 76-89.

Ancok, D. \& Suroso, F.N. (2011). Psikologi Islami. Yogyakarta: Pustaka Pelajar. Baiduri, R. (2020). Teori-Teori Antropologi Kebudayaan. Yayasan Kita Menulis.

Barone, D. M. (2011). Chlidren's Literature in the Classroom Engaging Lifelong Reader's. New York: The Guidford Press

Claudia, V. S., Suwandi, S., \& Wardani, N.E. (2021). Humanical Values and Enviromental Values in The Folklore at The Region Karangjati Distric. 4rd English Language and Literature International Conference (ELLiC) Proceedings, Vol. 4, 404-415.

Das, R. (2014). Psychoanalytical Study of Folktale. IOSR Journal of Humanities and Social Science (IOSRJHSS), 19(10), 13-18. https://doi.org/10.9790/0837191021318.

Dewi, Y. (2012). Nilai-nilai Pendidikan Religius dalam Dongeng Buku Teks Bahasa Indonesia Sekolah Menengah Pertama Kelas VII Terbitan Pusat Perbukuan Departemen Pendidikan Nasional. Jurnal Pena, 2(2), 71-83. http://online-journal.unja.ac.id/index.php/pena/article/view/1434 
Endraswara, S. (2013). Metodologi Peneltian Kebudayaan. Yogyakarta: Gadjah Mada University Press

Endraswara, S. (2009). Metodologi Penelitian Folkor. Yogyakarta: Med Press.

Fatimah, F. N., \& Sulistyo, E. T. (2017). “Cerita Rakyat Dewi Sri Tanjung sebagai Upaya Mewujudkan Pendidikan Karakter Berbasis Nilai Kearifan Lokal. Proceeding of 2nd International Conference of Arts Language and Culture. Surakarta: Universitas Sebelas Maret, 606-610, 4 November 20187.

Glock, C. \& Stark, R. (1966). Religion and Society in Tension. Chicago: University of California.

Haq, M. Z., (2012). Mangkunegara I: Kisah kepahlawanan dan Filosofi Perjuangan pangeran Samber Nyawa. Bantul: Kreasi Wacana.

Hastuti, S., Slamet, St.Y., Rakhmawati, A. (2021). The Legend of "Mbah Meyek" from Surakarta as A Medium Of Developing Creative Writing Competence on the Basis of Local Wisdom for University Students. Psychology and Education, 58(2), 4328-4334.

Hendro, E. P. (2017). Strategi Kebudayaan Perjuangan Pahlawan Nasional Pangeran Sambernyowo. Endogami: Jurnal Ilmiah Kajian Antropologi, 1(1), 42-54. 10.14710/endogami.1.1.42-54

Hijiriah, S. (2017). Kajian Struktur, Fungsi, dan Nilai Moral Cerita Rakyat sebagai Bahan Pembelajaran Apresiasi Sastra. Riksa Bahasa: Jurnal Bahasa, Sastra, dan Pembelajarannya, 3(1), 117-125. https://ejournal.upi.edu/ index.php/RBSPs/article/view/11819.

Iminisa, R. R., Siswanto, W., \& Basthomi, Y. (2016). Bentuk Karakter Anak melalui Dokumentasi Folklor Lisan Kebudayaan Lokal. Jurnal Pendidikan: Teori Penelitian Dan Pengembangan, 1(6), 996-1001

Juanda (2019). Nilai Pendidikan dalam Cerita Rakyat dan Perannya terhadap Pembentukan Karakter Siswa. Lingua (Jurnal Bahasa, Sastra, dan Pengajarannya), 15(2), 161-179.

Kasnadi \& Sutejo. (2018). Islamic Religious Values within Javanese Life Guidance. Jurnal el Harakah, 20(1), 33-47. https://dx.doi.org/10.18860/ el.v20i1.4850

el Harakah Jurnal Budaya Islam Vol. 23 No. 2, 2021 
Khan, F. (2018). The Concept of Folklore: An Overview of the Psychoanalytic Reading of Folklores. International Journal of English Literature and Social Sciences (IJELS), 3(6), 1059-1061. https://doi.org/10.22161/ijels.3.6.21.

Marsella, E. \& Putri, D.M. (2021). Folklore as Ethnic Embodiment Bias: Value Analysis on Karo Folklore. Bupadest International Research and Critics Institute (BIRCI-Journal): Humanities, 3(4), 2612-2628.

Maulidianto, H., Rokhmansyah, A., \& Dahri, D. (2021). Religiusitas dalam Cerita Rakyat Puan Sipinak. Ilmu Budaya: Jurnal Bahasa, Sastra, Seni, dan Budaya, 5(1), 28-38.

Maryone, R. (2021). Batu teteruga dan Cerita Rakyat Suku Sobey. Jurnal Arkeologi Papua, 13(1), 95-114.

Maryanto, D.A. \& Raharjanti, L. (2010). Cerita Rakyat dari Karanganyar (Jawa Tengah). Jakarta: Grasindo.

Muhaimin, A.M. (1991). Pemikiran Pendidikan Islam. Bandung: Bumi Aksara.

Nursari, S., Subiyantoro, S., \& Saddhono, K. (2020). Values of Islamic Teaching in Candung Kawik Folklore. Jurnal el Harakah, 22(1), 77-95.

Puspitasari, D., Andayani, \& Hastuti, S., (2018). Struktur Cerita dan Nilai Kepahlawanan dalam Cerita Rakyat di Kabupaten Karanganyar Sebagai Materi Ajar di Sekolah Menengah Pertama. BASASTRA Jurnal Penelitian Bahasa, Sastra Indonesia dan Pengajarannya, 6(1), 72-82. https://doi. org/10.20961/basastra.v6i1.37655

Putro, R. P, Rohmadi, M., Rakhmawati, A., \& Saddhono, K. (2021). Religiusitas Islam dalam Serat Wedhatama Pupuh Gambuh. Jurnal SMart (Studi Masyarakat, Religi, dan Tradisi), 7(1), 71-84.

Rahiem, M. D. H., \& Rahim, H. (2020). The Dragon, the Knight and the Princess: Folklore in Early Childhood Disaster Education. International Journal of Learning, Teaching and Educational Research (IJLTER), 19(8), 60-80. https://doi.org/10.26803/ijlter.19.8.4

Rahmaniar, F. S., Suyitno, S., Supana, S., \& Saddhono, K. (2020). Keselarasan Kearifan Lokal Dengan Nilai Keislaman Pada Tradisi Labuhan Gunung Kombang di Kabupaten Malang. Jurnal SMART (Studi Masyarakat, Religi, dan Tradisi), 6(1), 113-125. 
Rahyono, F. X. (2015). Kearifan Budaya dalam Kata (edisi revisi). Jakarta: Wedatama Widya Sastra

Rabbi, M, \& Jauhari, M. (2006). Keistimewaan Akhlak Islami. Bandung: Pustaka Setia.

Saddhono, K. \& Pramesthi, D. (2018). Sekar Macapat Pocung: Study of Religious Values Based on Javanes Local Wisdom. Jurnal el Harakah, 20(1), 15-31. http://dx.doi.org/10.18860/el.v20i1.4724

Saefudin, A., Pangestuti, D. N., \& Andriyani, S. (2020). Islamic Education Values of Barikan Javanese Cultural Rituals as A Practice of Islam Nusantara. Jurnal el Harakah, 22(2), 245-262. http://dx.doi.org/10.18860/ eh.v22i2.10217

Sari, F. K., Suwandi, S., \& Supana. (2018). Nilai-nilai Pendidikan Karakter dalam Makna Semiotik Legenda Aksara Jawa. Komposisi: Jurnal Pendidikan Bahasa, Sastra, dan Seni, 19(1), 47-63. http://dx.doi.org/10.24036/ komposisi.v19i1.8989

Sibarani, R. (2013). Folklor Nusantara: Hakikat, Bentuk, dan Fungsi (S. Endraswara (ed.). Ombak.

Singh, M. R., \& Devi, Y. P. (2020). Amalgamation of Folklore and Contemporary Issues in Girish Karnad's Hayavadana and Salman Rusdhie's Midnight's Children. Research Journal of English Language and Literature (RJELAL), 7(1), 2321-3108. https://doi.org/10.33329/rjelal.7119.57

Siswadi, Taruna. T., \& Purnaweni, H. (2011). Kearifan Lokal dalam Melestarikan Mata Air (Studi Kasus di Desa Purwogondo, Kecamatan Boja, Kabupaten Kendal). Jurnal Ilmu Lingkungan, 9(2), 63-68. http://ejournal.undip. ac.id/index.php/ilmulingkungan

Sujiono. (2019). Analisis Kajian Nilai Pendidikan dalam Cerita Rakyat Raden Wijaya di Kecamatan Trowulan Kabupaten Mojokerto. Purwadita: Jurnal Agama dan Budaya, 3(2), 43-50.

Sukardi, I. \& Sulidtyono, T. (2019). Manusia Jawa: Suatu Kajian Terhadap Serat Centini. Karanganyar: Surya Pustaka Ilmu.

Sumiyardana, K. (2018). Naga dalam Cerita Rakyat Jawa Tengah. Proseding Seminar Nasional Bulan Bahasa 1: Menduniakan Bahasa dan Sastra Indonesia.

el Harakah Jurnal Budaya Islam Vol. 23 No. 2, 2021 
Universitas PGRI Semarang: Fakultas Bahasa dan Sastra Indonesia. 7 November 2018.

Suryadi (2017). Persepsi Masyarakat Terhadap Kisah Pangeran Sambernyawa dan Nilai Pendidikan Karakternya. Jurnal Univetbantara, 39(1), 155-178. https://doi.org/10.32585/.v3i1.10

Wati, M.A., Sumarwati, \&Saddhono,K. (2019). Islamic Religious Values in Dhukutan Traditional Ceremony as Character Education for Elementary School Students. Jurnal el Harakah, 21(1), 65-81. http:// dx.doi.org/10.18860/el.v21i1.5615

Yayasan Mangadeg (1998). Pangeran Sambernyawa: Ringkasan Sejarah Perjuangannya. Surakarta: Rekso Pustaka

Zuriah, N. (2015). Pendidikan Moral dan Budi Pekerti dalam Perspektif Perubahan: Menggagas Platform Pendidikan Budi Pekerti secara Kontekstual dan Futuristik. Jakarta: Bumi Aksara 